\title{
Memory enhancing activity of extract of new citrus cultivar 'Shinyegam' in mice
}

\author{
Sang Suk Kim ${ }^{1}$, Ji Yong Park ${ }^{2}$, Won Chang Lee ${ }^{2}$, Chang-Yong Park ${ }^{2}$, \\ Bong-Hyon $\mathrm{Ko}^{2}$, Yoon-A Jeon ${ }^{2}$, Kyung Jin Park ${ }^{1}$, Hyun Joo An ${ }^{1}$, \\ Seok Beom Kang ${ }^{1}$, Su Hyun Yun ${ }^{1}$, Young Hun Choi ${ }^{1}$, Young Jae Lee ${ }^{2,3 *}$ \\ ${ }^{1}$ Citrus Research Institute, National Institute of Horticultural and Herbal Science, RDA, Jeju 63607, Korea \\ ${ }^{2}$ College of Veterinary Medicine, Jeju National University, Jeju 63243, Korea \\ ${ }^{3}$ Non-clinical Research Center, Jeju National University, Jeju 63243, Korea
}

\section{마우스에서 국내 육성 신품종 ‘신예감’ 추출물의 기억력 증진 효과}

\author{
김상숙 ${ }^{1}$ - 박지용 ${ }^{2}$ - 이원창 ${ }^{2} \cdot$ 박창용 $^{2} \cdot$ 고봉현 $^{2} \cdot$ 전윤아 $^{2} \cdot$ 박경진 $^{1} \cdot$ 안현주 $^{1}$ 강석범 $^{1}$. \\ 윤수현 ${ }^{1} \cdot$ 최영훈 $^{1} \cdot$ 이영재 $2,3 *$ \\ ${ }^{1}$ 국립원예특작과학원 감귤연구소, ${ }^{2}$ 제주대학교 수의과대학, ${ }^{3}$ 제주대학교 비임상연구센터
}

\begin{abstract}
A new mandarin hybrid cultivar called 'Shinyegam' was developed from a cross between 'Kiyomi' (Citrus unshiu $\times C$. sinensis) and 'Wilking' (Citrus reticulata) at the Citrus Research Institute of the National Institute of Horticultural and Herbal Science in 2012. The 'Shinyegam' was extracted with 70\% ethanol (SYGE), and polyphenol content was measured to assess total antioxidant activity of flavonoids. Radical scavenging activities of the extracts were examined using a-a-diphenyl- $\beta$-picrylhydrazyl (DPPH), 2,2-azino-bis 3-ethylbenzthiazoline-6-sulfonic acid (ABTS), and ferric reducing antioxidant power (FRAP) assays. SYGE showed high polyphenol and flavonoid content as well as strong DPPH, ABTS, and FRAP radical scavenging activity. We used a mouse model to assess the memory enhancing properties of SYGE and its ameliorating activities on learning and memory impairments. Drug-induced amnesia was initiated by scopolamine treatment $(2 \mathrm{mg} / \mathrm{kg}$, interperitoneal). SYGE administration $(25 \mathrm{mg} / \mathrm{kg}$, oral) significantly enhanced cognitive function and attenuated scopolamine-induced cognitive impairments as determined by novel object recognition, passive avoidance and Y-maze tasks. In addition, SYGE increased brain-derived neurotrophic factor (BDNF) expression in the hippocampus. These results suggest that SYGE enhances learning and memory in normal states and attenuates memory loss caused by cholinergic dysfunction.
\end{abstract}

Key words : citrus, Shinyegam, antioxidant activity, passive avoidance test, Y-maze test, novel objective recognition, scopolamine

\section{서 론}

현대인에게 기억력은 사회적으로 학습량이 많은 청소년

*Corresponding author. E-mail : yjlee3@jejunu.ac.kr

Phone : 82-64-754-3371, Fax : 82-64-756-3354

Received 28 September 2018; Revised 20 November 2018;

Accepted 28 November 2018.

Copyright (c) The Korean Society of Food Preservation. All rights reserved.
에서부터 노년에 이르기까지 주요 관심 대상이 되고 있다. 특히 노인인구 비율 증가 추세의 사회에서 치매와 같은 퇴행성 질병 환자의 사회생활 가능 여부는 기억력 저하가 매우 중요한 요소이기도 하다(1). 건망증과 치매는 기억력 에 문제가 생기는 비슷한 증상을 보이지만 건망증은 공간적 인 맥락에서 과거와 현재를 연결하는 기억현상에 차질이 발생하는 것으로 개선이 가능한 반면 치매는 단기기억뿐 아니라 기억력 전체가 심각하게 손상되어 판단력과 언어능 력, 작업능력도 현저히 떨어지는 차이를 보인다. 치매의 
가장 대표적인 유형은 알츠하이머병으로, 65 세 이상 치매 환자의 $70 \%$ 가 알츠하이머병으로 기억력 및 판단력의 감퇴 와 같은 뇌 기능 저하와 언어 능력 저하 등의 임상적인 특징을 보인다 $(2,3)$. 이러한 기억력을 포함한 인지능력의 저하는 학습저하, 사회활동 위축, 이로 인한 삶의 질 저하 등을 초래하게 되므로 신경세포보호 효과 등이 뛰어난 천연 자원의 개발이 요구되고 있다.

예로부터 다양한 생리활성 성분을 함유하고 있는 천연물 은 여러 질병 치료에 사용되어 왔으며, 특히 감귤류는 비타 민C, 엽산, 카로티노이드, 리모노이드 등 다양한 기능성 성분을 함유하고 있으며 항산화, 항암, 항염증 등의 효과를 갖는 플라보노이드 60 여 종이 존재하는 것으로 알려져 있 다(4). 감귤에 포함되어 있는 플라보노이드는 narirutin, naringin, hesperidin 등의 배당체와 naringenin과 hesperetin 등의 비배당체 형태로 존재한다. 감귤류의 플라보노이드는 과피에 집중적으로 존재하며, flavanones은 과피의 안쪽 흰 색 부위인 알베도층에 가장 많고, flavones은 과피의 황색부 분인 플라베도 조직에 많이 분포한다(5). 감귤류의 과피는 동양의학에서 기관지와 천식 환자에게 사용되어 왔으며 최근에는 감염성 질환이나 암 등을 예방한다고 보고되고 있다. 특히 감귤류에는 채소나 다른 과일에서는 보고되지 않은 polymethoxylated flavones(PMF) 중 nobiletin과 tangeretin이 함유되어 있으며, 이들 PMF는 혈소판 응집 억제, 임파구 증식 억제, 항궤양, 항염증 등의 생리활성을 나타내는 것으로 보고되고 있다(6,7).

본 연구에서는 사용된 감귤 신품종 '신예감'은 국립원예 특작과학원 감귤연구소에서 2002년에 '청견'(Citrus unshiu $\times$ C. sinensis)에 'Wilking'(C. reticulate)을 교배하여 육성된 품종이다. 2008년 과실특성 조사 후 계통명 '제감 나-33호' 를 부여하였고, 2010년에서 2012년 제주특별자치도 5개 지역에서 지역적응 시험을 거쳐 최종 선발되었다. 과중은 $130 \mathrm{~g}$ 정도이고 모양은 편구형으로 약간 편평하고 껍질은 진한 오렌지색이다. 과실의 성숙시기는 12 월 하순경으로 성숙기 과실의 당도는 $11-12{ }^{\circ} \mathrm{Brix}$, 산 함량은 $1 \%$ 내외이다. 과육은 부드럽고 과즙량이 많은 편이며 향기는 'Wilking'과 유사하나 약한 편이다. 신품종 '신예감'은 온주밀감과 유사 하면서 향기가 있고 당도가 높으며 겨울철 노지재배가 가능 한 품종이다(8). 국내 노지재배 감귤 품종의 다양화와 겨울 철에도 노지재배가 가능한 고품질 감귤 품종 육성을 위해 개발된 감귤 신품종 '신예감'의 유용성분을 분석하고 이를 이용하여 항산화 활성과 인지능 개선 효과를 확인하고자 하였다.

\section{재료 및 방법}

\section{실험재료}

국내 육성 신품종인 신예감은 감귤연구소에서 2017년
1 월 과실을 채취한 후 깨끗이 세척하고 $60^{\circ} \mathrm{C}$ 건조기에서 $12-48$ 시간 건조 시킨 후 분쇄하여 사용하였다. 신예감 추출 물(SYGE)은 건조 시료 $2 \mathrm{~g}$ 에 $70 \%$ 메탄올 $40 \mathrm{~mL}$ 를 가하여 초음파 추출기로 1 시간 동안 추출하고, 상층액을 $0.45 \mu \mathrm{m}$ syringe filter로 여과한 후 감압 농축하고 동결 건조하여 시료로 사용하였다.

\section{$\mathrm{HPLC}$ 를 이용한 플라보노이드 분석}

플라보노이드 성분 분석을 위한 시료는 $10,000 \mathrm{ppm}$ 농도 로 준비하여 $0.22 \mu \mathrm{m}$ PVDF filter(millipore)로 여과한 후 HPLC(e2695 Separations module, Waters Co., Ltd., Miliford, $\mathrm{MA}, \mathrm{USA})$ 를 이용하여 분석하였다. 분석에 사용한 column 은 YMC-Triart $\mathrm{C}_{18}, 250 \times 4.6 \mathrm{~mm}, \mathrm{~S}-5 \mu \mathrm{m}, 8 \mathrm{~nm}$ 을 사용하였 고 detector는 UV/Visible Detector(Waters 2489, Waters Co., Ltd.)을 사용하였다. 유속은 $2 \mathrm{~mL} / \mathrm{min}$ 을 유지하였고 UV $280 \mathrm{~nm}$ 에서 검출하였다. 정량을 위해서 감귤류에 많이 함 유되어 있다고 알려진 rutin, narirutin, naringin, hesperidin, neohesperidin은 이동상 조건이 acetonitrile: $20 \mathrm{mM}$ phosphoric acid $=2: 8$ 이다. Quercetin, naringenin, hesperetin 은 이동상 조건이 acetonitrile: $20 \mathrm{mM}$ phosphoricacid=4:6으 로 수행하였고, nobiletin과 tangeretin의 이동상 조건은 acetonitrile: $20 \mathrm{mM}$ phosphoric acid=6:4로 수행하였으며 모 든 시약은 HPLC grade를 사용하였다. 표준물질은 $\mathrm{MeOH}$ 과 $\mathrm{DMSO}$ 를 이용하여 녹인 다음 혼합하여 각각 200,100 , $50,25 \mathrm{ppm}$ 이 되도록 순차적으로 희석하여 사용하였고, 데이터 분석 S/W는 Waters의 Empower System을 사용하였 다.

\section{총 폴리페놀과 총 플라보노이드 함량 측정}

총 폴리페놀 함량 측정은 Folin-Denis(9)법을 이용하여 측정하였다. 농도별로 희석하여 준비된 $1 \mathrm{~mL}$ 의 신예감 추 출물에 Folin-Ciocalteu's phenol reagent $100 \mu \mathrm{L}$ 를 첨가하여 실온에서 5 분간 반응 후 $\mathrm{Na}_{2} \mathrm{CO}_{3}$ 용액 $(7 \%, \mathrm{w} / \mathrm{v}) 200 \mu \mathrm{L}$ 와 증류수 $700 \mu \mathrm{L}$ 를 넣어 실온에서 1 시간 반응시켰다. 반응 후 $720 \mathrm{~nm}$ 에서 흡광도를 측정하였고, gallic acid를 이용하 여 작성한 표준검정곡선을 이용하여 추출물의 총 폴리페놀 함량을 나타내었다. 총 플라보노이드 함량 측정을 위해서 는 Moreno 등(10)의 방법을 이용하여 추출물 $15 \mu \mathrm{L}$ 에 diethylene glycol $150 \mu \mathrm{L}, 1 \mathrm{~N} \mathrm{NaOH} 15 \mu \mathrm{L}$ 를 첨가하여 혼합한 후 상온에서 1시간 반응시키고 ELISA reader (SpectraMax ${ }^{\circledR}$ M3 Multi-Mode Microplate Reader(Molecular Devices, Sunnyvale, CA, USA)를 사용하여 $420 \mathrm{~nm}$ 에서 흡 광도를 측정하였다. Quercetin을 표준물질로 작성한 표준검 정곡선을 이용하여 추출물의 총 플라보노이드 함량을 나타 내었다.

\section{DPPH radical scavenging 활성 측정}

$\mathrm{DPPH}$ 라디칼 소거 활성 실험은 Blois 방법(11)을 이용하 
여 사용하였다. $0.2 \mathrm{mM}$ 로 준비된 $\mathrm{DPPH}$ 와 시료를 혼합하고 실온에서 10 분간 방치한 후 ELISA reader(SpectraMax ${ }^{\circledR} \mathrm{M} 3$ Multi-Mode Microplate Reader(Molecular Devices)를 사용하 여 $517 \mathrm{~nm}$ 에서 흡광도를 측정하였다. $\mathrm{DPPH}$ 의 흡광도가 $50 \%$ 감소할 때 나타나는 시료의 농도 $\left(\mathrm{SC}_{50}\right)$ 로 표시하였으 며, 각 시료는 3회 반복실험을 실시하여 평균값을 구하였다. 이 때 사용된 대조군으로는 vitamin $\mathrm{C}$ 를 사용하였다.

DPPH radical scavenging effect $(\%)=\left(1-\frac{B-C}{A}\right) \times 100$
$\mathrm{A}$ : DPPH 용액의 흡광도
$\mathrm{B}$ : 시료자체의 흡광도
$\mathrm{C}$ : DPPH 용액과 시료 반응액의 흡광도

\section{ABTS radical scavenging 활성 측정}

ABTS radical 소거활성은 $7.4 \mathrm{mM} \mathrm{ABTS}$ 와 $2.6 \mathrm{mM}$ potassium persulfate를 혼합 후 실온 암소에서 15시간 동안 방치하여 radical을 형성시킨 후 이 용액을 $734 \mathrm{~nm}$ 에서 흡광 도 값이 $0.70 \pm 0.02$ 가 되도록 준비하였다. 준비된 $\mathrm{ABTS}$ 용 액 $180 \mu \mathrm{L}$ 에 추출물 $20 \mu \mathrm{L}$ 를 가하여 실온에서 15 분 동안 방치한 다음 $734 \mathrm{~nm}$ 에서 흡광도를 측정하였다. ABTS radical 소거활성은 시료 용액의 첨가구와 무첨가구 사이의 흡광도 차이를 백분율로 나타내었다.

ABTS radical scavenging effect $(\%)=\left(1-\frac{\mathrm{B}-\mathrm{C}}{\mathrm{A}}\right) \times 100$
$\mathrm{A}: \mathrm{ABTS}$ 흡광도
$\mathrm{B}$ : $\mathrm{ABTS}$ 와 시료 반응액의 흡광도
$\mathrm{C}$ : 시료자체의 흡광도

\section{FRAP법에 의한 항산화 활성 측정}

Ferric reducing antioxidant power(FRAP)법에 의한 항산 화 활성은 Benzie와 Strain(12)의 방법에 따라 실시하였다. $300 \mathrm{mM}$ acetate buffer(pH 3.6), $10 \mathrm{mM}$ 2,4,6-tripyridyl -s-triazine(TPTZ)가 용해된 $40 \mathrm{mM} \mathrm{HCl}$ 용액과 $20 \mathrm{mM}$ $\mathrm{FeCl}_{3} \cdot 6 \mathrm{H}_{2} \mathrm{O}$ 를 각각 $10: 1: 1(\mathrm{v} / \mathrm{v} / \mathrm{v})$ 의 비율로 혼합하여 FRAP 기질액으로 사용하였다. 96-well plate에 다양한 농도의 시 료 $40 \mu \mathrm{L}, \mathrm{FRAP}$ 기질액 $100 \mu \mathrm{L}$ 와 증류수 $200 \mu \mathrm{L}$ 를 차례로 혼합하여 $37^{\circ} \mathrm{C}$ 에서 4 분간 반응시킨 후 $593 \mathrm{~nm}$ 에서 흡광도 를 측정하였다. 각 시료는 3 회 반복하여 실시하였고, $\mathrm{FeSO}_{4} \cdot 7 \mathrm{H}_{2} \mathrm{O}$ 를 표준물질로 하여 얻은 표준검정곡선을 이 용하여 분석하였다.

\section{실험동물 사육 및 실험군의 구성}

ICR 수컷 마우스를 (주대한바이오링크(DBL, Eumseong, Korea)로부터 구입하여 1 주간 제주대학교 실험동물사육실 환경에 적응시킨 후 실험에 사용하였다. 실험동물사육실 환경은 온도 $23 \pm 2^{\circ} \mathrm{C}$, 상대습도 $50 \pm 10 \%$ 이었으며, 명암주기 는 12시간 단위(조명시간 08:00-20:00)로 조절되었다. 물과 사료는 자유섭취시켰다. 실험동물은 정상대조군, scopolamine 투여군(기억력 손상 유발군) 및 신예감 $(25 \mathrm{mg} / \mathrm{kg} /$ day, p.o.) 처리군으로 분류하고, 각 군마다 8 마리씩 배치하여 2 주간 실험하였다. 기억력손상유발군은 scopolamine $(2 \mathrm{mg} / \mathrm{kg} / \mathrm{day}$, i.p.)을 7일간 복강 투여하였으며(scopolamine 투여군)(13), 신예감 처리군은 scopolamine을 투여하기 7일전부터 매일 14 일간 경구투여 $(25 \mathrm{mg} / \mathrm{kg} /$ day, p.o.)하였으며, 투여 8 일째 부터 14 일까지는 scopolamine $(2 \mathrm{mg} / \mathrm{kg} / \mathrm{day}$, i.p.)을 동시에 투여하였다. 정상대조군은 각 물질의 부형제로 사용된 생 리식염수를 투여하였다. 인지기능 및 기억력 평가는 투여 14일 째에 수행하였으며, 마지막 시료 투여 4시간 후에 실험 동물을 희생시켜 뇌를 적출하여 $-70^{\circ} \mathrm{C}$ 에 보관하였다. 본 연구에서의 모든 동물실험은 제주대학교 동물실험 윤리위 원회의 승인 하에 수행되었다(승인번호: 2016-0037).

\section{물체 인지능력 테스트(novel objective recognition test: NOR test)}

마우스를 검은 색 플라스틱 상자 $(40 \times 40 \times 27 \mathrm{~cm})$ 에 넣어 적응 시키고, 재질, 모양과 색상 및 크기 $(2.7 \times 2.7 \times 5 \mathrm{~cm})$ 가 동일한 2 개의 물체 $(\mathrm{A}, \mathrm{A} 1)$ 를 넣은 뒤 5 분 동안 각 물체에 흥미를 가지는 시간을 측정하였다. 1 시간 후 마우스가 상대 적으로 관심을 덜 가지는 물체(A)를 새로운 물체(B)로 바꾸 어 주고 다시 5 분 동안 관심도를 측정하였다. 새로운 물체 (각 변이 $5.7 \mathrm{~cm}$ 인 피라미드형)는 기존 물체와 동일한 재질 과 색상으로 모양과 크기만 다른 상태로, 마우스가 코나 앞발로 물체를 만지는 경우 물체에 흥미가 있는 것으로 판단하였다. 물체 인지능력은 새로운 물질 탐색에 소요된 시간을 측정하여 전체 탐색 시간에 대한 비율, 즉 변별지수 (discrimination index; DI)를 구하여 판단하였다.

$$
\mathrm{DI}(\%)=\frac{\mathrm{B}}{\mathrm{A} 1+\mathrm{B}} \times 100
$$
$\mathrm{A} 1$ : 바꾸지 않은 물체에 흥미를 보였던 시간
$\mathrm{B}$ : 바꾼 물체에 흥미를 보였던 시간

\section{$\mathrm{Y}$-미로시험(Y-maze test)}

사용된 실험 장치는 검은색 아크릴 판 $(10 \times 41 \times 25 \mathrm{~cm})$ 으 로 $\mathrm{Y}$ 자 모양의 사방이 막힌 미로로 제작되었으며, 각 미로 는 서로 $120^{\circ}$ 의 일정한 각도로 배치되어 있다. Y-maze의 세 개의 가지를 $\mathrm{A}, \mathrm{B}, \mathrm{C}$ 로 정한 후 한쪽에 마우스를 놓고 
8 분 동안 마우스가 들어간 가지의 이동 경로를 기록하였다. 세 곳의 다른 영역에 순차적으로 들어간 경우 1 점(실제변경 : actual alteration, 즉 $\mathrm{ABC}, \mathrm{BCA}, \mathrm{CAB}$ 등의 순서)으로 인정 하였으며, 연속되게 들어가지 않은 경우는 점수로 인정하 지 않았다.

$\%$ 변경행동력(\% spontaneous alteration)은 다음과 같다.

$\%$ spontaneous alteration $=\frac{\text { 총 alteration 수 }}{\text { 총 입장 회수-2 }} \times 100$

\section{수동회피 시험(passive avoidance test)}

Passive avoidance test는 dark chamber와 조명이 있는 light chamber 2 개의 구역으로 구분되어 있으며 바닥은 stainless 철망으로 이루어져있다. 각 mouse는 dark chamber에서 1 분 동안 우선 적응시켰다. 적응이 끝난 후 light chamer에 쥐를 위치시킨 1초 후에 door가 열리고, 쥐가 dark chamber로 들어가면 1 초 후에 문이 닫히고, $0.3 \mathrm{~mA}$ 의 전기충격이 2 초 동안 가해진다. 학습 시험을 시킨 다음날 각 mouse들을 대상으로 기억 시험(test trial)을 실시하였다. 조명을 켠 light chamber에 mouse를 놓고 mouse의 네 발이 다 들어가는데 걸리는 시간(latency time)을 180 초까지 측정하였다(14).

\section{Western blotting}

실험 종료 후 마우스를 희생시켜, 뇌를 적출한 후 해마 부위에 lysis buffer를 첨가하여 30분간 용해(lysis)시킨 후 $16,000 \times g$ 에서 20 분간 원심 분리하여 세포막 성분 등을 제거하였다. 단백질 농도는 bovine serum albumin(BSA)를 표준화하여 Bio-Rad Protein Assay Kit를 사용하여 정량하 여 20-30 $\mathrm{\mu g}$ 의 lysate를 8-12\% mini gel SDS-PAGE로 변성 분리하여, 이를 polyvinylidene difluoride(PVDF) membrane (BIO-RAD, Richmond, CA, USA)에 $200 \mathrm{~mA}$ 로 2시간 동안 transfer 하였다. Transfer 후 membrane의 blocking은 5\% skim milk가 함유된 TTBS( $0.1 \%$ Tween 20+TBS) 용액에서 상온에서 2시간 동안 실시하였다. Brain-derived neurotrophic factor(BDNF)의 발현 양을 검토하기 위한 항체 로는 anti-mouse $\operatorname{BDNF}(1: 1,000)$ (Calbiochem, La Jolla, CA, USA)를 사용하였고, TTBS 용액에서 희석하여 상온에서 2 시간 반응시킨 후 TTBS로 3 회 세정하였다. 2 차 항체로는 horse radish peroxidase(HRP)가 결합된 anti-mouse $\mathrm{IgG}$ (Amersham Pharmacia Biotech, Little Chalfont, UK)를 $1: 5,000$ 으로 희석하여 상온에서 30 분간 반응시킨 후, TTBS 로 3회 세정하여 $\mathrm{ECL}$ 기질(Amersham Biosciences, Piscataway, NJ, USA)과 1-3분간 반응 후 Chemidoc(Fusion solo, VILBER LOURMAT, Detschland, Germany)을 이용하 여 단백질 발현정도를 확인하였다.

\section{통계분석}

모든 실험은 3회 이상 반복하여 이루어졌으며, 실험 결과 는 각 항목에 따라 평균과 표준편차로 나타내었다. 실험군 과의 차이는 SAS package(SAS Institute Inc., Cary, NC, USA)를 사용하여 Duncan's mutiple range test로 평균을 비 교하여 나타내었고, $\mathrm{p}<0.05$ 수준에서 통계적 유의성을 검정 하였다.

\section{결과 및 고찰}

\section{HPLC를 이용한 SYGE의 flavonoid 분석}

'신예감'은 2002년 감귤연구소에서 '청견'(Citrus unshiu $\times$ C. sinensis)에 'Wilking'(C. reticulata)을 교배하여 나온 교배실생으로 제주도내 지역별 특성 조사를 거친 후 2012 년 최종 선발·명명하였으며 2015년 국립종자원에 품종 등 록되었다(8). 신예감은 온주밀감과 유사하면서 향기가 있 고 당도가 높으며 겨울철 노지재배가 가능한 감귤류이다. 이러한 신예감 추출물(SYGE)의 flavonoid 분석을 위해 HPLC를 이용하여 표준물질 rutin, narirutin, naringin, hesperidin, neohesperidin, quercetin, naringenin, hesperetin, nobiletin, tangeretin로 함유량을 분석하였다. 그 결과 주요 하게 rutin, narirutinm hesperidin, nobiletin, tangeretin을 확인 할 수 있었으며, hesperidin $>$ narirutin $>$ nobiletin $>$ tangeretin $>$ rutin의 순으로 함유되어 있는것을 확인할 수 있었다. 가장 함량이 높은 hesperidin은 금속이온과 착염의 기능으로 활 성 산소를 억제하여 세포, 조직, 기관 손상을 억제하고 노화 방지, 항암, 모세혈관 보호와 콜레스테롤을 낮춰주는 역할 을 하는 것으로 알려져 있으며, 추출물에 함유되어 있는 hesperidin의 함량은 $100 \mathrm{~g}$ 당 $1,018 \mathrm{mg}$ 으로 가장 높았다 (Table 1). 특히 신예감 추출물에는 감귤류에 다량 함유되어 있는 polymethoxyflavonoid 중 항바이러스, 항암, 항염 등의 활성과 reactive oxygen species(ROS) 또는 염증반응으로부 터 피부를 보호하는 역할을 하는 것으로 알려져 있는

Table 1. Flavonoid contents in 'Shinyegam'

(unit: g\%)

\begin{tabular}{ccc}
\hline Flavonoids & Peel & Flesh \\
\hline Rutin & $34.37 \pm 3.0^{1)}$ & $17.9 \pm 0.0$ \\
Narirutin & $645.20 \pm 51.2$ & $315.62 \pm 30.4$ \\
Hesperidin & $1,018.50 \pm 89.1$ & $555.54 \pm 50.0$ \\
Nobiletin & $517.9 \pm 43.9$ & $\mathrm{ND}^{2)}$ \\
Tangeretin & $90.37 \pm 6.8$ & $\mathrm{ND}$ \\
\hline
\end{tabular}

${ }^{1}$ The data represent the mean $\pm \mathrm{SD}$ of three determinations.

${ }^{2)}$ No detected. 
nobiletin(15-17)과 항암 활성이 있는 것으로 알려진 tangeretin(18)의 함량이 517.9 와 $90.37 \mathrm{mg} / 100 \mathrm{~g}$ 으로 다량 함유되어 있었다.

\section{SYGE의 항산화 활성}

SYGE의 항산화 활성 측정을 위해 total polyphenol 함량, total flavonoid 함량, DPPH 라디칼 소거활성, ABTS radical 소거활성, FRAP 활성을 측정하였다. 식물체에 특수한 색을 부여하고 산화-환원 반응에서 기질로 작용하는 polyphenol 은 한 분자내에 2 개 이상의 phenolic hydroxyl $(\mathrm{OH})$ 기를 갖는 방향족 화합물로 플라보노이드와 탄닌이 주성분이다. 이러 한 polyphenol의 총량은 gallic acid를 표준물질로 측정한 결과 SYGE에는 $4.65 \mathrm{~g} \mathrm{GAE} / 100 \mathrm{~g}$ 이 함유되어 있었으며, total flavonoid는 $1.79 \mathrm{~g} \mathrm{QE} / 100 \mathrm{~g}$ 으로 다량 함유되어 있다.

유용 성분을 다량 함유하고 있는 SYGE의 항산화 효능을 확인하기 위해 단순하면서도 간편하게 시료의 전자 공여에 의한 라디칼 소거 활성을 측정할 수 있는 $\mathrm{DPPH}, \mathrm{ABTS}$ 라디칼 소거 활성과 산화 환원 반응에 의한 메카니즘으로 항산화 활성을 측정할 수 있는 $\mathrm{FRAP}$ 를 측정하였다. $\mathrm{DPPH}$ 의 라디칼을 소거하여 탈색되는 점(19)과 $\mathrm{ABTS}$ 와 potassium persulfate와의 반응에 의해 생성된 ABTS 라디칼 이 항산화력에 의해 전자를 받아 무색의 물질로 환원되는 $\mathrm{ABTS}$ 라디칼 소거 활성(20)을 농도별 $(0.78,0.156,0.312$, $0.625,1.25,2.5 \mathrm{mg} / \mathrm{mL})$ 로 준비된 시료를 이용하여 라디칼 의 $50 \%$ 가 저해되는 활성 $\left(\mathrm{SC}_{50}\right)$ 을 확인하였다(Table 2). 그 결과 $\mathrm{DPPH}$ 와 $\mathrm{ABTS}$ 라디칼 소거활성에 대한 $\mathrm{SC}_{50}$ 이 각각 $2.08 \pm 0.19,0.24 \pm 0.021 \mathrm{mg} / \mathrm{mL}$ 인 것을 확인할 수 있었으며, 항산화 활성은 시료의 농도가 증가함에 따라 소거 활성도 증가하는 것을 확인할 수 있었다. 또한 $\mathrm{DPPH}$ 라디칼 소거 활성과는 다른 FRAP 방법은 낮은 $\mathrm{pH}$ 에서 환원제에 의해 ferric tripyridyltriazine( $\left.\mathrm{Fe}^{3+}-\mathrm{TPTZ}\right)$ 복합체가 ferrous tripyridyltriazine( $\mathrm{Fe}^{2+}$-TPTZ)으로 환원되는 원리를 이용한 것으로, 대부분의 항산화제가 환원력을 가지고 있다는 특 징을 이용하여 개발된 방법이다(13). FRAP 측정 결과

Table 2. Total polyphenol content (TPC), total flavonoid content (TFC), and antioxidant capacity (measured by DPPH, ABTS, and FRAP methods) in SYGE

\begin{tabular}{lccccc}
\hline Sample & $\begin{array}{c}\mathrm{TPC}^{1)} \\
(\mathrm{g} / 100 \mathrm{~g})\end{array}$ & $\begin{array}{c}\mathrm{TFC}^{2)} \\
(\mathrm{g} / 100 \mathrm{~g})\end{array}$ & $\begin{array}{c}\mathrm{DPPH} \\
\left(\mathrm{SC}_{50},\right. \\
\mathrm{mg} / \mathrm{mL})\end{array}$ & $\begin{array}{c}\mathrm{ABTS}_{\left(\mathrm{SC}_{50,}\right.} \\
\mathrm{mg} / \mathrm{mL})\end{array}$ & $\begin{array}{c}\mathrm{FRAP}^{3)} \\
\left(\mathrm{Fe}^{2+} \mu \mathrm{mol} / \mathrm{g} \text { of }\right. \\
\text { extract basis })\end{array}$ \\
\hline SYGE & $4.65 \pm 0.31^{4)}$ & $1.79 \pm 0.12$ & $2.08 \pm 0.19$ & $0.24 \pm 0.021$ & $123.2 \pm 10.21$ \\
\hline
\end{tabular}

${ }^{11}$ Micrograms of total polyphenol content/100 g of sample based on gallic acid as a standard.

${ }^{2)}$ Micrograms of total flavonoid content/100 $\mathrm{g}$ of sample based on quercetin as a standard.

${ }^{3)}$ Micrommole of total $\mathrm{Fe}^{2+} / \mathrm{mg}$ of sample based on $\mathrm{FeSO}_{4} \cdot 7 \mathrm{H}_{2} \mathrm{O}$ as a standard.

${ }^{4)}$ Each value is mean \pm SD $(n=3)$.
$123.2 \pm 10.21 \mathrm{umol} / \mathrm{g}$ 의 환원력을 보였으며, 환원력은 체내 에 생성된 과산화지질 및 활성 산소를 제거하여 성인병을 예방하는 효과가 있어 환원반응을 통한 체내 항상성을 유지 하는 활성이 높을수록 그 이용가치가 크다고 할 수 있다.

\section{SYGE의 물체 인지능력 테스트(novel objective recognition test: NOR test)}

새로운 물체인지실험은 뇌 속의 해마에 의해 주관되는 인지기능 중에 가장 깊이 연관되어 있는 기억력 평가의 행동실험 중 하나로 동물이 처음 접하는 물체나 환경에 호기심을 느끼고, 탐색하는 시간을 가진 다음 그 물체 및 환경을 기억하여 해마에 저장하게 되는 것을 이용한 실험이 다. 동물은 해마에 저장되어 있는 정보를 바탕으로 동일한 물체나 환경에 대한 인식 시간이 줄어들게 되므로, 새로운 물체 인지 실험은 해마의 정보저장 및 인지 능력을 확인하 는 방법이다(21). 본 연구에서는 scopolamine을 처리하여 기억력 감퇴를 유발한 동물 모델을 이용하여 SYGE가 기억 력 손상을 억제하는 효과가 있는지를 확인하고자 하였다. 정상 동물 모델에 동일한 두 물체를 제시하면 자연스럽게 호기심이 유발되어 두 물체를 탐지하게 되는데 이때 일반적 으로 두 물체를 탐지하는 횟수가 비슷하다. 24시간 후 두 물체 중 하나를 새로운 물체로 교체시키면 정상적인 mouse 는 새로운 물체에 대해 더 많은 호기심을 가지는 습성때문 에 새로운 물체를 탐지하는 횟수가 더 증가하게 된다. 그러 나 기억력이 손상된 동물모델의 경우 새로운 물체와 기존의 물체를 구분해내지 못해 두 물체 간 탐지 횟수가 큰 차이를 나타내지 않게 된다. 물체인지 실험 결과를 살펴보면 scopolamine을 처리하지 않은 경우에는 새로운 물체 인지 비율이 $60 \%$, scopolamine 처리군의 경우 $36 \%$ 이었고, SYGE

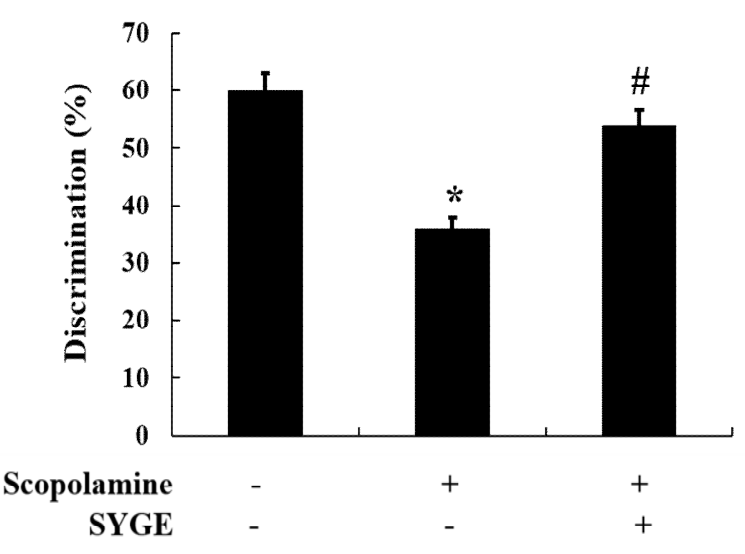

Fig. 1. Effect of SYGE on the novel object recognition test.

For the investigation on the scopolamine-induced memory deficit model, memory impairment was induced by scopolamine treatment $(2 \mathrm{mg} / \mathrm{kg}$, I.p.) and SYGE $(25 \mathrm{mg} / \mathrm{kg})$ was treated. For percentage change in object cognitive ability test, the time that the mice spent with the novel object was recorded. Data represent mean $\pm \operatorname{SEM}(\mathrm{n}=8)$. ${ }^{*} \mathrm{p}, 0.005$ versus control group; \#p, 0.005 versus scopolamine group. 
처리군의 경우 대조군과 유사한 $54 \%$ 로 호기심으로 접촉 빈도가 높은 것으로 보아 SYGE가 기억력 개선에 효과가 있음을 확인할 수 있었다(Fig. 1).

\section{SYGE의 Y-maze 시험에서의 효과}

단기기억 형태의 공간인지력을 평가하는 Y-maze 시험에 의한 spontaneous alternation과 total entry는 Fig. 2 와 같이 대조군과 scopolamine, SYGE 처리군에서 유의한 차이를 확인할 수 있었다. Scopolamine 처리군의 경우 기억력이 손상되어 spontaneous alternation 점수가 평균 $48 \pm 5.12 \%$ 인 반면 대조군의 경우 평균 $60 \pm 7.5 \%$ 이었다. 한편 scopolamine 으로 기억력 감소를 유발한 후 SYGE를 $25 \mathrm{mg} / \mathrm{kg}$ 으로 처리 한 경우 spontaneous alternation 점수가 평균 $58 \pm 4.5 \%$ 로 통 계적으로 유의성있게 증가하였음을 확인할 수 있었다(Fig. 2). 그러나 각 구역으로 들어가는 총 횟수를 나타내는 total entry에서는 변화가 없는 것으로 보아 spontaneous alternation

(A)

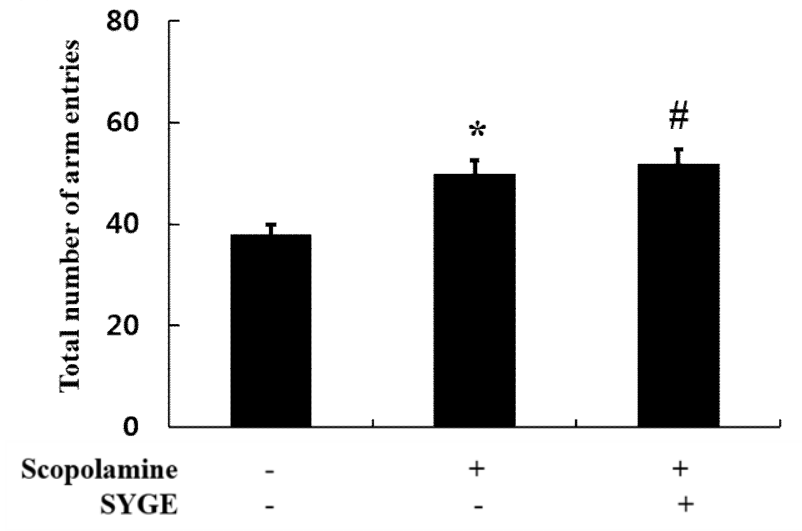

(B)

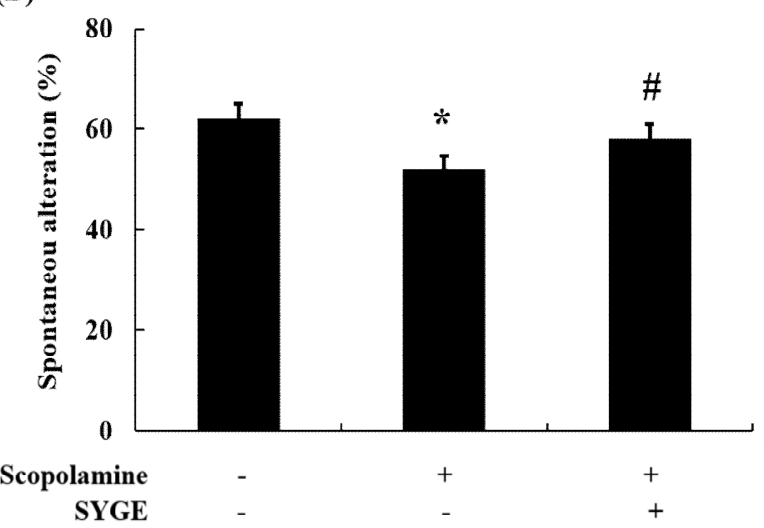

Fig. 2. Effect of SYGE on the Y-maze test.

A, total number of arm entries; B, spontaneous alternation.

For the investigation on the scopolamine-induced memory deficit model, memory impairment was induced by scopolamine treatment $(2 \mathrm{mg} / \mathrm{kg}$, I.p.) and SYGE $(25 \mathrm{mg} / \mathrm{kg})$ was treated. While scopolamine induced an impairmmt in spatial working memory and an increase in locomotor activity, spontaneous alternation behavior and number of arm entries during $8 \mathrm{~min}$ session were measured. Data represent mean $\pm \operatorname{SEM}(n=8)$. ${ }^{*} p, 0.05$ versus control group; \#p, 0.05 versus scopolamine group.
이 마우스의 활동성 변화에 의해 나타난 것이 아님을 알 수 있었다(22,23).

\section{SYGE의 수동회피 시험에서의 효과}

준비된 기억력 감퇴 동물모델에서 $\mathrm{SYGE}$ 이 기억력 손상 을 억제하는 효과가 있는지 여부를 수동회피 측정 장치를 이용하여 확인하였다. Scopolamine 투여에 의한 기억력 감 퇴 모델 실험에서 scopolamine $(2 \mathrm{mg} / \mathrm{kg})$ 의 투여에 의해 latency time이 대조군의 $300 \pm 10.2$ 초인데 비해 $230 \pm 9.5$ 초로 유의성 있게 감소하는 것을 확인할 수 있었다(Fig. 3). 이는 학습시험(acquisition trial)시의 전기 자극을 기억하지 못한 다는 것으로 판단되어 scopolamine에 의한 기억력 감퇴모델 이 잘 만들어졌다고 판단되었다. 또한 scopolamine 처리로 기억력이 감퇴된 동물 모델에 SYGE을 $25 \mathrm{mg} / \mathrm{kg}$ 의 용량으 로 경구투여했을 시 latency time이 $290 \pm 7.8$ 초로 유의적으 로 증가하는 것을 확인하여 기억력 개선 효과가 있음을 확인할 수 있었다.

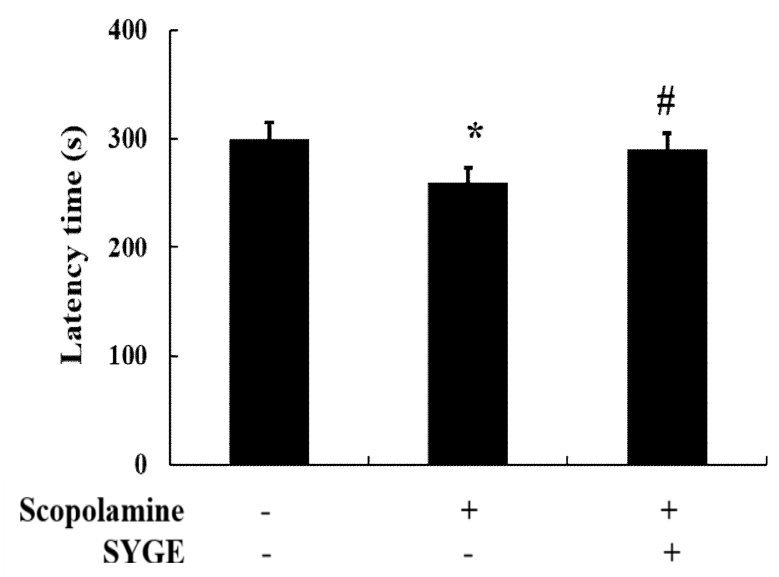

Fig. 3. Effect of SYGE on the passasive test.

For the investigation on the scopolamine-induced memory deficit model, memory impairment was induced by scopolamine treatment $(2 \mathrm{mg} / \mathrm{kg}$, I.p.) and SYGE $(25 \mathrm{mg} / \mathrm{kg})$ was treated. Data represent mean $\pm \mathrm{SEM}(\mathrm{n}=8)$. ${ }^{*}, 0.05$ versus control group; \#p,0.05 versus scopolamine group.

\section{BDNF 단백질 발현}

기억력 증진에 SYGE가 미치는 효과 기전을 알아보기 위해, 장기 기억과 밀접한 연관이 있는 것으로 알려진 BDNF 단백질 발현 정도를 western blot analysis를 통해 알아보고자 하였다(24). 행동 실험에서의 효과 용량인 25 $\mathrm{mg} / \mathrm{kg}$ 의 SYGE를 마우스에 처리하여 $\mathrm{BDNF}$ 의 발현 정도를 분석하였고, 그 결과는 Fig. 4에 나타내었다. 대조군인 무처 리군에서는 $\mathrm{BDNF}$ 의 발현이 정상적으로 이뤄졌으며, $\mathrm{BDNF} / \beta$-actin의 비율이 0.4 정도 나타났다. 한편 기억력 감퇴 유발을 위해 scopolamine을 처리한 군에서는 $\mathrm{BDNF}$ 의 발현량이 감소하였으며, $\mathrm{BDNF} / \beta$-actin의 비율이 0.1 이하 인 것을 확인할 수 있었다. Scoplamine의 처리로 기억력을 감퇴시킨 군에 SYGE를 $25 \mathrm{mg} / \mathrm{mL}$ 으로 처리하였을 때 
$\mathrm{BDNF}$ 의 발현량이 증가하고 $\mathrm{BDNF} / \mathrm{\beta}$-actin 비율 역시 0.7 정도로 증가한 것을 확인할 수 있었다. $\mathrm{BDNF}$ 는 신경세포의 생존과 기능의 발달에 영향을 끼치는 neurotrophin의 한 종 류로 신경세포의 생존과 기능의 발달에 영향을 끼치며, 신 경세포의 생존 외에도 신경세포와 시냅스의 성장 및 분화를 촉진하는 것으로 알려져 있다 $(25,26)$. 또한 $\mathrm{BDNF}$ 는 뇌에서 학습 및 기억분야와 밀접한 관련이 있으며, 특히 장기기억 의 저장과 널리 연구되고 있는 학습 및 기억의 세포 모델인 long-term potentiation의 형성에 중요한 역할을 한다고 알려 져 있다(27,28). BDNF 발현에 영향을 미치는 SYGE는 행동 시험에서 보여주는 기억력 증진 효과가 $\mathrm{BDNF}$ 의 발현의 증가로 인한 것일 수 있음을 제시한다. 이러한 결과들을 보아 기억력 감퇴 개선 효과 및 증진 효과가 탁월한 신예감 추출물(SYGE)를 인지능 개선제 및 기억력 증진제 소재로 활용할 수 있는 가능성을 확인하였다.

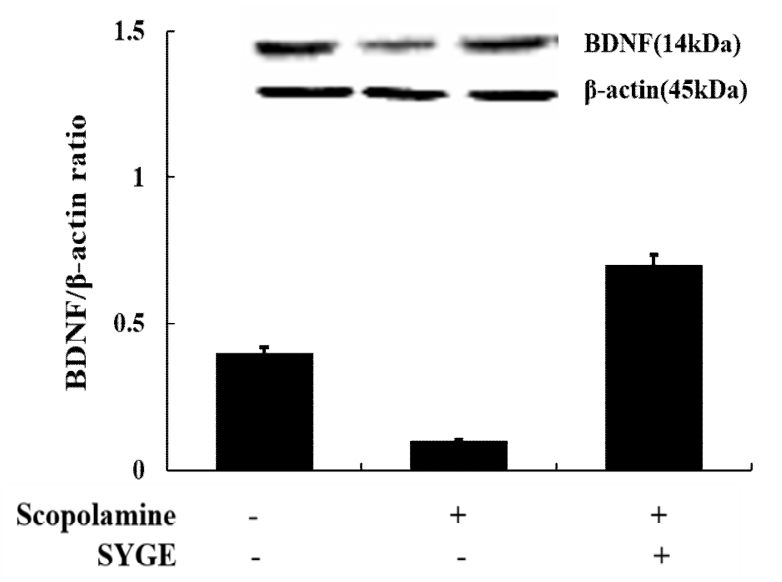

Fig. 4. Effect of SYGE $(25 \mathrm{mg} / \mathrm{kg})$ on the protein abundance of BDNF.

The photographs represent the temporal profiles of BDNF expression in the hippocalpal tissues after SYGE treatment $(25 \mathrm{mg} / \mathrm{kg})$. The graph displays densitometiric analysis of the expression ration of $\mathrm{BDNF} / \beta$-actin normalized to the control group. Data represent mean $\pm \operatorname{SEM}(n=8)$.

\section{요 약}

신예감은 '청견'에 'Wilking'을 교배하여 나온 교배 실생 으로 국립원예특작과학원 감귤연구소에서 2012년도에 개 발한 품종이다. 신예감의 수확 시기는 12 월에서 1 월로 온주 밀감 수확이 끝나는 12 월부터 이듬해 2월 수확되는 만감류 가 나오기 전에 수확이 가능한 품종으로 당도가 $12{ }^{\circ} \mathrm{Brix}$, 산함량 $1.0 \%$ 이하이다. 신예감은 탄골류로 항암, 항염, 항산 화 등의 활성이 알려진 polymethoxyflavonoid(PMF) 중 nobiletin과 tangeretin의 함량이 과피에서 가장 높았으며 시 기적으로는 미숙과 $(212.706,41 \mathrm{ppm})$ 시기의 함량이 완숙과 $(41.26,7.21 \mathrm{ppm})$ 시기보다 높았다. PMF 함량이 높은 신예 감 추출물을 이용하여 동물실험을 실시한 결과 인지능 개선
효과를 확인할 수 있었다. 인지능 개선 효과 확인을 위해서 새로운 물체 인지능력 평가, Y-maze test인 공간인지능 검사 와 뇌유래 신경 영양인자 발현 시험을 실시하였다. 그 결과 새로운 물체 인지능력에서는 뇌기능억제제인 스코폴라민 을 처리한 쥐에 신예감 추출물을 투입한 결과 $50 \%$ 의 새로 운 물체 인지능 개선 효과를 확인할 수 있었다. 또한 공간인 지능 검사에서 역시 $28 \%$ 의 인지능 개선 효과를 확인할 수 있었다. 이는 뇌유래 신경 영양인자인 brain derived neurotrophic factor(BDNF) 단백질의 발현에서도 나타났는 데 기억 장애현상이 발생하면 $\mathrm{BDNF}$ 의 발현양이 감소하고 신예감 추출물을 처리하였을 때 발현양이 증가되어 기억력 장애 현상을 개선하는 효과가 있음을 확인할 수 있었다. 본 연구 결과를 통해 감귤인지능 개선용 기능성 식·의약 소재로서의 이용 가능성을 확인할 수 있었다.

\section{감사의 글}

본 성과물은 농촌진흥청 연구사업(세부과제: PJ010934032017) 의 지원에 의해 이루어진 것입니다.

\section{References}

1. Oh SK (2005) Neurotransmetters and brain disease. Shinil Books company, Seoul, Korea, p 345-364

2. Crapper DR, DeBoni U (1978) Brain aging and Alzheimer's disease. Can Psychiatr Assoc J, 23, 229-233

3. Boller F, Mizutani T, Roessmann U, Gambetti P (1980) Parkinson disease, dementia, and Alzheimer disease: clinicopathological correlations. Ann Neurol, 7, 329-335

4. Horowitz RM, Gentili B (1977) Flavonoid constituents of citrus. In: Citrus Science and Technology, Nagy S, Shaw PE, Veldhuis MK (Editor), AVI Publishing Co Inc, Westport, CT, USA, p 397-426

5. Nogata Y, Sakamoto K, Shiratsuchi H, Ishii T, Yano M, Ohta H (2006) Flavonoid composition of fruit tissues of citrus species. Biosci Biotechnol Biochem, 70, 178-192

6. Lee SG, Ra JH, Song JY, Gwak CH, Kwon HJ, Yim SV, Hong SP, Kim JJ, Lee KH, Cho JJ, Park YS, Park CS, Ahn HJ (2011) Extracts from Citrus unshiu promote immune-mediated inhibition of tumor growth in a murine renal cell carcinoma model. J Ethnopharmacol, 133, 973-979

7. Li S, Pan MH, Lo CY, Tan D, Wang Y, Shahidi F, Ho CT (2009) Chemistry and health effects of polymethoxyflavones and hydroxylated polymethoxy 
flavones. J Funct Foods, 1, 2-12

8. Yun SH, Park JH, Park SM, Koh SW, Lee DH, Moon YI, Choi YH, Kim MJ, Kang SB, Chae CW, Jin SB (2016) Development of an early maturing mandarin cultivar, 'Shinyegam'. Korean J breed sci, 48, 499-503

9. Singleton VL, Orthofer R, Lamuela-Raventos RM (1999) Analysis of total phenols and other oxidation substrates and antioxidants by means of Folin-Ciocalteu reagent. Methods Enzymol, 299, 152-178

10. Moreno MIN, Isla MI, Sampietro AR, Vattuone MA (2000) Com-parison of the free radical-scavenging activity of propolis from several regions of Argentina. J Ethnopharmacol 71, 109-114

11. Blois MS (1958) Antioxidant determinations by use of a stable free radical. Nature, 181, 1199-1200

12. Benzie IFF, Strain JJ (1996) The ferric reducing ability of plasma (FRAP) as a measure of "antioxidant power": The FRAP assay. Anal Biochem, 239, 70-76

13. Rahnama S, Rabiei Z, Alibabaei Z, Mokhtari S, Rafieian-Kopaei M, Deris F (2015) Anti-amnesic activity of Citrus aurantium flowers extract against scopolamineinduced memory impairments in rats. Neurol Sci, 36, 553-560

14. Kim MJ, Choi SJ, Lim ST, Kim HK, Heo HJ, Kim EK, Jun WJ, Cho HY, Kim YJ, Shin DH (2007) Ferulic acid supplementation prevents trimethyltin-induced cognitive deficits in mice. Biosci Biotech Bioch, 71, 1063-1068

15. Guo S, Qiu P, Xu G, Wu X, Dong P, Yang G, Zheng J, McClements DJ, Xiao H (2012) Synergistic anti-inflammatory effects of nobiletin and sulforaphane in lipopolysaccharide-stimulated RAW 264.7 cells. J Agric Food Chem, 60, 2157-2164

16. Suzuki M, Sasaki K, Yoshizaki F, Fujisawa M, Oguchi K, Cyong JC (2005) Anti-hepatitis C virus effect of Citrus unshiu peel and its active ingredient nobiletin. Am J Chin Med, 33, 87-94

17. Yoshimizu N, Otani Y, Saikawa Y, Kubota T, Yoshida M, Furukawa T, Kumai K, Kameyama K, Fujii M, Yano M, Sato T, Ito A, Kitajima M (2004) Anti-tumour effects of nobiletin, a citrus flavonoid, on gastric cancer include: antiproliferative effects, induction of apoptosis and cell cycle deregulation. Aliment Pharmacol Ther, 20, 95-101

18. Bracke ME, Vyncke BM, Van Larebeke NA, Bruyneel EA, De Bruyne GK, De Pestel GH, De Coster WJ, Espeel
MF, Mareel MM (1989) The flavonoid tangeretin inhibits invasion of MO4 mouse cells into embryonic chick heart in vitro. Clin Exp Metastasis, 7, 283-300

19. Lee JJ, Kim AR, Chang HC, Lee MY (2009) Antioxidative effects of chungkukjang preparation by adding solar salt. Korean J Food Preserv, 16, 238-245

20. Re R, Pellegrini N, Proteggente A, Pannala A, Yang M, Rice-Evans C (1999) Antioxidant activity applying an improved ABTS radical cation decolorization assay. Free Radic Biol Med, 26, 1231-1237

21. Bevins RA, Besheer $J$ (2006) Object recognition in rats and mice: a one-trial non-matching-to-sample learning task to study 'recognition memory'. Nat Protoc, 21, 1306-1311

22. Hasegawa Y, Inone T, Kawaminami S, Fujita M (2016) Effect of scallop shell extract on scopolamine-induced memory impairment and MK801-induced locomotoe activity. Asian Pac J of Trop Med. 9, 662-667

23. Walrave L, Vinken M, Albertini G, Bundel D, Leybaert L, Smolders IJ (2016) Inhibition of connexin43 hemichannels impairs spatial short-term memory without affecting spatial working memory. Front Cell Neurosci, 10, $1-10$

24. Bekinschtein P, Cammarota M, Katche C, Slipczuk L, Rossato JI, Goldin A, Izquierdo I, Medina JH (2008) $\mathrm{BDNF}$ is essential to promote persistence of long-term memory storage. Proc Natl Acad Sci USA, 105, 2711-2716

25. Acheson A, Conover JC, Fandl JP, DeChiara TM, Russell M, Thadani A, Squinto SP, Yancopoulos GD, Lindsay RM (1995) A BDNF autocrine loop in adult sensory neurons prevents cell death. Nature, 374, 450-453

26. Huang EJ, Reichardt LF (2001) Neurotrophins: roles in neuronal development and function. Annu Rev Neurosci, 24, 677-736

27. Bramham CR, Messaoudi E (2005) BDNF function in adult synaptic plasticity: the synaptic consolidation hypothesis. Prog Neurobiol, 76, 99-125

28. Kuipers SD, Bramham CR (2006) Brain-derived neurotrophic factor mechanisms and function in adult synaptic plasticity: new insights and implications for therapy. Curr Opin Drug Discovery Dev, 9, 580-586 